\section{Yesterday's malaria wars}

Robert S. Desowitz

The Tomorrow of Malaria. By Socrates Litsios. Pacific Press, New Zealand. Distributed by Natural History Book Service: 1996. Pp. 181. \$18 (pbk).

THE Tomorrow of Malaria is, in large part, the chronicle of yesterday's malaria wars - a hundred years' conflict fought as much between malariologists as against the parasite. This is the centenary of Ronald Ross's discovery of the transmission of bird malaria through the mosquito. The super-sensitive, single-minded Ross went to his grave still holding the firm conviction that malaria could be eradicated if only weak-willed governments would commit themselves to exploit his discovery and attack the anopheline in their watery lairs.

On the other side were those who considered malaria to be a social disease. Malaria would disappear only when the economic life of the subjugated populations improved. Good housing, good nutrition, good health and education services, and modern agricultural practices were the best antimalarials. The anopheline without the parasite was only another biting nuisance. Economic betterment was advanced as the cause of the disappearance of malaria from northern Europe and England where more than 10,000 cases had been admitted to London's St Thomas's Hospital alone between 1860 and 1870 , followed by a rapid decline to four or five cases each year by 1925 .

Schismatics soon arose on each side. The technocrats divided into the chemical-therapy camp led by the German bacteriologist Robert Koch, who believed malaria should be drugged into submission, and the vector-control camp led by the Englishmen Malcolm Watson and L. W. Hackett and the Americans Fred Soper and Paul Russell, who maintained the Rossian stand of selective anopheline control. The sociocrats split into the active-betterment camp and a 'do nothing' camp which maintained, on the basis of prevailing immunological fact and theory, that holoendemic malaria led to a benign state in adults. The unfortunate wastage of the young was a necessary, worthwhile cost in the community's journey to functional immunity. Those technocrat-sociocrat wars were fought in the 'bow and arrow' era of malariology. Quinine was the only thera- peutic drug, and pyrethrum and Paris green the only insecticides. Then the Second World War ended, the pesticide DDT was rediscovered and the World Health Organization (WHO) embarked on its global crusade to eradicate malaria.

\section{IMAGE UNAVAILABLE FOR COPYRIGHT REASONS}

Socrates Litsios, the WHO insider and tion of malaria would do - impure thoughts of 'control' could lead to excommunication. A strict, universal formula for DDT application and surveillance was imposed on all national programmes. A timetable to eradication was promised.

In his book, Litsios rarely makes a direct comment or expresses an opinion. But his description of events and selection of citations speak for his sentiments. In this way, he condemns WHO for being too inflexible; for imposing a universal prescription when each setting required a programme to accommodate its vectors, its parasites and its human population's culture, behaviour and economy. Litsios faults WHO for not realizing that the massive reservoir of malaria, sub-Saharan Africa, was undoable. Nor did they appreciate the political-economic pressures on the new $\circlearrowleft$ governments then emerging from

$\approx$ colonial paternalism that would distract from the national malaria campaign.

The final chapter, "The Tomorrow of Today", is the sobering account of malaria's current annual toll - 300 million cases with 2 million deaths. DDT is gone. Cheap, effective chemo-therapeutics and prophylactics are gone. Multiinsecticide and multi-drug resistance are here. Steady-state, benign (for adults) holoendemic malaria has been replaced, in many settings, by unstable hyperendemicity - functional immunity impaired by the ad hoc chemotherapy distributed from the primary health centres. It is déjà $v u$ all over again as the technocrat-sociocrat wars continue. The molecular technocrats now offer the unfulfilled, over-hyped, crimetainted promise of a vaccine. Nonmolecular technocrats offer bed nets dipped in permethrin. In one of his few displays of direct feeling, Litsios, in this final chapter, reveals himself to be the humane sociocrat: "The aim should be to improve the quality of life, with regard to human dignity, the realization of people's potentials, and the achievement of a decent standard of living. This implies a radical revision of established practices."

This is a fine, powerful little book. I would make all molecular-malaria graduate students read it before they clone their first gene or make their first hybridoma. Come to that, I would insist that their mentors read it too.

Robert S. Desowitz is in the Department of Epidemiology, School of Public Health, University of North Carolina at Chapel Hill, Chapel Hill, North Carolina 27599, USA. 